\title{
Assessment of Socio-Demographic Factors with Knowledge and Attitiudes of Pakistani Married Women (15-49 Years) towards HIV/AIDS Transmission
}

\author{
Rukiya Tariq $^{1 *}$, Quratulain Bashir ${ }^{2}$ and Tanzeel UI Rahman ${ }^{3}$ \\ 'Public Health, Department of Public Health, University of the Punjab, Lahore, Pakistan; rukiyatariq17@gmail.com \\ ${ }^{2}$ Hospital Pharmacist, Patient Welfare Association, Jinnah Hospital, Lahore, Pakistan \\ ${ }^{3}$ Regional Training Institute, Population Welfare Department Punjab, Lahore, Pakistan
}

\begin{abstract}
Introduction: Despite of improvement in knowledge, diagnostics, prevention and treatment; HIV/AIDS is highly discriminated and stigmatized worldwide. Objective: To determine the association of various socio-demographic characteristics with knowledge and attitudes towards HIV/AIDS transmission among married women. Study Design and Setting: For this purpose, secondary analysis was done using data from Multiple Indicator Cluster Survey (MICS) 2014. Materials and Methods: Study design was cross-sectional. Only ever married women were included as participants of the study. Result: Significant associations were found between sociodemographic factors i.e., women age ( $p$-value $=0.001$ ), women education ( $p$-value $=0.001$ ), wealth index ( $p$-value $=0.001$ ), access to media ( $p$-value $=0.001)$, type of place of residence $(p$-value $=0.01)$, marital status $(p$-value $<0.05)$ with knowledge and attitudes of women towards HIV/AIDS. Conclusion: Despite of having high odds of appropriate knowledge of HIV/AIDS transmission; attitudes of Pakistani women towards HIV/AIDS transmission were still negative. Programs need to be designed in order to reverse the negative attitudes of community towards HIV/AIDS transmission.
\end{abstract}

Keywords: Knowledge, Attitude, Married Women, HIV/AIDS, MICS

\section{Introduction}

Despite remarkable improvement in information, diagnostics, treatment and prevention of the disease in past two decades, HIV/AIDS is still a serious threat to public health in particular and to society in general ${ }^{1-4}$. Over 1.1 million HIV positive individuals reside in United States and approximately $20 \%$ individuals were unaware of the infection ${ }^{5}$. Estimates reveal that at the end of 2013, almost 35 million people were living with HIV infection and 1.5 million HIV related deaths were recorded worldwide ${ }^{6}$. HIV infection is more concentrated in Sub-Saharan Africa, approximately one in twenty adults is HIV positive. Almost sixty nine percent of the HIV positive individuals were from the same region ${ }^{7}$. First HIV case in Pakistan was identified in 1987 and after that the infection had spread to a large extent ${ }^{8}$; approximately 98,000 people were living with HIV in 2009 and the main reasons for HIV/AIDS spread include unawareness, undiagnosed cases and unsafe sexual practices .
Alarmingly low level of knowledge regarding HIV/AIDS was the main key for spread of HIV/AIDS infection. A study by Faust, Yaya and Ekholuenetale ${ }^{10}$ investigated that women who were poor, residing in rural areas and low literacy levels than women with highest wealth inequality ratios had less knowledge towards HIV/AIDS transmission; thus enables execution of future evidence-based interventions among women in order to reduce HIV/AIDS transmission. Age, education and mass media such as listening radio, watching television and reading newspaper or magazine can also play an important role in increasing knowledge towards HIV/AIDS transmission among both ever married men and women ${ }^{9}$. A research conducted by Subaeti and his co-associates ${ }^{11}$ identified that married women were more vulnerable to HIV/ AIDS infection because married people did not use condoms during sexual activities; therefore were at greater risk of getting HIV/AIDS infection. Though level of knowledge towards HIV/ AIDS transmission was increased but still negative attitudes towards HIV/AIDS was observed ${ }^{12-15}$.

${ }^{*}$ Author for correspondence 
This was further supplemented by taboos surrounding discussions about sexuality which limit the implementation of preventive activities ${ }^{16}$. Moreover, certain misconceptions regarding spread of HIV/AIDS also exist in Pakistani society. However, the number of HIV/AIDS infected individuals was being increased and to deal with this health challenge, politically supported comprehensive programs are required ${ }^{8}$. The present study aimed to determine the association of various sociodemographic variables with knowledge and attitudes towards HIV/AIDS transmission among married women.

\section{Methodology}

The study design was cross-sectional. Data was derived from MICS Punjab, 2014 (Pakistan) and secondary analysis was done ${ }^{17}$. HIV/AIDS module was administered to ever married women 15-49 years of age. All the variables were derivatives of women's datasets of $2014(\mathrm{~N}=61286)$. As the research study hypothesized that socio-demographic factors determine the knowledge and attitude of women (15 to 49 years) towards HIV/AIDS transmission, therefore, sample was restricted to the variables who gave valid response to all the outcomes as well as independent variables. After removing records with missing data, the number of women included in the final analysis was 13390 women aged 15 to 45 years.

\subsection{Description of Measures}

\subsubsection{Dependent Variables}

The two dependent variables (knowledge and attitude) were used for this study:

\subsubsection{Women's knowledge on HIV/AIDS transmission}

MICS measure women knowledge about HIV/AIDS transmission by the following nine criteria:

- Knowing the two most common methods to prevent HIV/ AIDS infection:

a. Limiting the number of sexual partners to one un-infected partner who is faithful.

b. Consistent condom use.

- Being able to reject the four common misconceptions about the disease in the region:

c. People can get HIV/AIDS virus through supernatural means.

d. Person can get HIV/AIDS from a mosquito bite.

e. By sharing meal; person can get HIV/AIDS from an infected individual. f. Person looking in good health or healthy cannot have HIV/AIDS.

- Knowing the ways from which HIV/AIDS transmission occurs:

g. Mother to child during pregnancy

h. Mother to child during delivery

i. Mother to child through breastfeeding

MICS measures the above indicator questions as yes, no and don't know. This research dichotomize knowledge scale scoring into 1 (yes/correct) and 0 (no/incorrect or don't know); thus compositing (higher) scores signified well knowledge about HIV/AIDS prevention. Missing responses were re-coded as 9 and were excluded from the analysis. Thus, knowledge score ranges from 0-9. Respondents who correctly answered five or more than five out of nine questions means they had good and appropriate knowledge about HIV/AIDS; whereas respondents who responded less than five questions had poor or inappropriate knowledge about HIV/AIDS.

\subsubsection{Women's attitude towards HIV/AIDS transmission}

The women's attitude toward HIV/AIDS transmission was measured by the following four MICS questions:

a. Would you want to keep undisclosed HIV/AIDS infection from family members?

b. Would you take care of a relative who is HIV/AIDS infected?

c. Would you buy vegetables from seller with an HIV/ AIDS virus?

d. Should a female educator allowed to proceeds education in school with HIV/AIDS infection?

MICS categorizes above questions as yes, no and don't know. The research re-codes (i.e., dichotomizing each item) attitude scale scores into 1 (yes for positive answer) and 0 (no or don't know for negative answer); thus composite (higher) score reflects better attitude toward HIV/AIDS. Women with missing responses were excluded from the analysis. Thus, attitude score ranges from 0 to 4 . Respondents who had two or more attitude scale score were characterized as positive attitude group whereas; respondents less than two attitude scale score as negative attitude group.

\subsubsection{Independent Variables}

Owing to the study objectives and to make the bivariate analysis possible; age was categorized as 15-30 years, 31-45 years and 45 and above years with the goal of determining the effect of 
increase age has on the women's HIV/AIDS knowledge and attitudes; women education as no formal education (absence of schooling), primary education (1-5 class), secondary education (5-10 class) and higher education (above 10 classes); place of residence into urban and rural regions and only those couples who are residing at the same household were considered for this study ${ }^{8}$; marital status as being single (including widowed/ divorced/separated) and married ${ }^{18}$.

Household wealth status as conceptualized in MICS was divided into 5 categories i.e., poorest (lowest), poor, middle, rich and richest (highest) income groups. Family unit (households) who had lowest score on all the assets items i.e., no electricity and one sleeping room, poor or low floor material, toilet facility and water supply were mentioned as poorest. Whereas; households (family unit) who holds all the assets items i.e. availability of electricity, three or more sleeping rooms, good floor material, toilet facility and water supply were mentioned as richest. Rest of the categories is in between these two categories ${ }^{19,20}$. Respondent's access to media i.e., reading newspaper or magazine, listen to the radio and watch television was hypothesized by using three categories: not at all, sometimes and almost every day ${ }^{21}$ having a score of 0,1 and 2 respectively for each mass media type.

\subsection{Data Analysis}

Descriptive statistics was used to estimate the frequency distributions of socio-demographic characteristics with knowledge and attitude towards HIV/AIDS transmission among 15 to 49 years age women through IBM SPSS Statistics Version 21. Bivariate logistic regression and distributions of dependent variables across independent variables were tested by applying Chi-square (p-value) test of associations. Odd ratios were calculated with $95 \%$ Confidence Interval (CI) as well as p-value less than 0.05 (significant).

\section{Results}

\subsection{Knowledge of Respondents towards HIV/ AIDS Transmission}

To evaluate knowledge on HIV/AIDS transmission, respondents were asked list of questions (Table 1). Respondents with correct responses included as avoid HIV/AIDS cross-infection by limiting number of sexual partners to one uninfected partner (62\%), condom use (64\%); transmission from mother to child during pregnancy (76\%); delivery (71\%) and breastfeeding (68\%) were graded as Appropriate Knowledge. Whereas, respondents with wrong responses had misconceptions about transmission through supernatural means (11\%), mosquito bites $(84 \%)$, sharing food $(0.5 \%)$ and healthy looking person (37\%) may have the infection were listed as Inappropriate Knowledge.

\subsection{Attitude of Respondents towards HIV/AIDS} Transmission

To evaluate attitude towards HIV/AIDS transmission, respondents were asked list of following questions (Table 2); representing low magnitudes of respondents (women) with positive attitude. Respondents with correct responses included as $1 \%$ should female educator be allowed to proceeds education in school, $0.5 \%$ stated that they would buy fresh vegetables from seller and $37 \%$ reported willing to care if their household member gets infected with HIV/AIDS were graded as Positive Attitude. Whereas, respondents with wrong response included as 38\% remaining a secret if household member got infected with HIV/AIDS were listed as Negative Attitude.

Table 1. Respondents knowledge towards HIV/AIDS transmission $(\mathrm{N}=13390)$

\begin{tabular}{|c|c|c|}
\hline Questions on respondents knowledge towards HIV/AIDS transmission & Frequency & Percentage \\
\hline $\begin{array}{l}\text { Do you have knowledge of HIV/AIDS cross-infection control by limiting the number of sexual partners to } \\
\text { one un-infected partner (yes) }\end{array}$ & 8302 & $62 \%$ \\
\hline Do you think that HIV/AIDS virus can be caused by supernatural means (yes) & 1473 & $11 \%$ \\
\hline Do you think that HIV/AIDS infection can be avoided by consistent condom use (yes) & 8570 & $64 \%$ \\
\hline Do you think that HIV/AIDS infection transmitted from mosquito bite (no) & 11248 & $84 \%$ \\
\hline Do you think that HIV/AIDS infection can be transmitted by sharing meal of HIV/AIDS infected person (no) & 67 & $0.5 \%$ \\
\hline Belief that person looking in good health or healthy cannot have HIV/AIDS(no) & 4954 & $37 \%$ \\
\hline Knowledge of HIV/AIDS transmission from mother to child during pregnancy (yes) & 10176 & $76 \%$ \\
\hline Knowledge of HIV/AIDS transmission from mother to child during delivery (yes) & 9507 & $71 \%$ \\
\hline Knowledge of HIV/AIDS transmission from mother to child through breastfeeding (yes) & 9105 & $68 \%$ \\
\hline
\end{tabular}


Table 2. Respondents attitude towards HIV/AIDS transmission $(\mathrm{N}=13390)$

\begin{tabular}{|l|l|l|}
\hline Questions on respondents attitude towards HIV/AIDS transmission & Frequency & Percentage \\
\hline Should female teacher with HIV/AIDS be allowed to teach in school (yes) & 134 & $1 \%$ \\
\hline Would you buy fresh vegetables from shopkeeper with HIV/AIDS (yes) & 67 & $0.5 \%$ \\
\hline If household member became infected with HIV/AIDS, would you want it to remain a secret (no) & 5088 & $38 \%$ \\
\hline Willing to care for person with HIV/AIDS in household (yes) & 4954 & $37 \%$ \\
\hline
\end{tabular}

\subsection{Characteristics of the Respondents (women) Selected for the Study}

Descriptive analysis (Table 3) of research study presents the characteristics of 13390 (15-49 years old) women presented

\begin{tabular}{|c|c|c|}
\hline Variables & Frequency & Percentage \\
\hline Age of Women (years) & $\begin{array}{l}\text { Mean } \pm \text { Standard } \\
\text { Deviation }\end{array}$ & $32 \pm 10.2$ \\
\hline $\begin{array}{l}15-30 \\
31-45 \\
46 \text { and above }\end{array}$ & $\begin{array}{l}3979 \\
4531 \\
4880\end{array}$ & $\begin{array}{l}29.7 \% \\
33.8 \% \\
36.5 \%\end{array}$ \\
\hline \multicolumn{3}{|c|}{ Type of Place of Residence } \\
\hline $\begin{array}{l}\text { Rural } \\
\text { Urban }\end{array}$ & $\begin{array}{l}6300 \\
7090 \\
\end{array}$ & $\begin{array}{l}47 \% \\
53 \% \\
\end{array}$ \\
\hline \multicolumn{3}{|l|}{ Marital Status } \\
\hline $\begin{array}{l}\text { Married } \\
\text { Single a }\end{array}$ & $\begin{array}{l}6546 \\
6844 \\
\end{array}$ & $\begin{array}{l}48.9 \% \\
51.1 \% \\
\end{array}$ \\
\hline \multicolumn{3}{|l|}{ Women Education } \\
\hline $\begin{array}{l}\text { No formal education } \\
\text { Primary } \\
\text { Secondary } \\
\text { Higher }\end{array}$ & $\begin{array}{l}2262 \\
3511 \\
3694 \\
3923 \\
\end{array}$ & $\begin{array}{l}16.9 \% \\
26.2 \% \\
27.6 \% \\
29.3 \% \\
\end{array}$ \\
\hline \multicolumn{3}{|l|}{ Wealth Index } \\
\hline $\begin{array}{l}\text { Poorest } \\
\text { Poor } \\
\text { Middle } \\
\text { Rich } \\
\text { Richest }\end{array}$ & $\begin{array}{l}2453 \\
2351 \\
2431 \\
2763 \\
3392 \\
\end{array}$ & $\begin{array}{l}18.3 \% \\
17.6 \% \\
18.2 \% \\
20.6 \% \\
25.3 \% \\
\end{array}$ \\
\hline \multicolumn{3}{|l|}{ Access to media } \\
\hline $\begin{array}{l}\text { Not at all } \\
\text { Sometimes } \\
\text { Almost everyday }\end{array}$ & $\begin{array}{l}3362 \\
4638 \\
5390 \\
\end{array}$ & $\begin{array}{l}25.1 \% \\
34.6 \% \\
40.3 \% \\
\end{array}$ \\
\hline \multicolumn{3}{|c|}{ Comprehensive Knowledge } \\
\hline $\begin{array}{l}\text { Appropriate knowledge } \\
\text { Inappropriate knowledge }\end{array}$ & $\begin{array}{l}5490 \\
7900 \\
\end{array}$ & $\begin{array}{l}41 \% \\
59 \% \\
\end{array}$ \\
\hline \multicolumn{3}{|l|}{ Attitude } \\
\hline $\begin{array}{l}\text { Positive attitude } \\
\text { Negative attitude }\end{array}$ & $\begin{array}{l}1071 \\
12319 \\
\end{array}$ & $\begin{array}{l}08 \% \\
92 \% \\
\end{array}$ \\
\hline \multicolumn{3}{|c|}{ a Single (separated, widowed and divorced) } \\
\hline
\end{tabular}

mean age and standard deviation as $32 \pm 10.2$; defining knowledge as appropriate and inappropriate knowledge has percentages $41 \%$ and $59 \%$ respectively and attitudes as positive and negative having percentages $8 \%$ and $92 \%$ respectively.

\subsection{Socio-Demographic Characteristics of the Respondents with Respect to their Knowledge and Attitude towards HIV/AIDS Transmission}

The research study aims to assess socio-demographic characteristics with respect to knowledge on HIV/AIDS and attitude towards HIV/AIDS (Table 4). Among 13390, 5490 (41\%) had appropriate knowledge and 7900 (59\%) had inappropriate knowledge towards HIV/AIDS transmission. Among 5490, highest appropriate knowledge i.e., 2531 (46.1\%) were found among those who belonged to age group 46 and above; 1877 (34.1\%) belonged to age group 31 to 45 years and lowest appropriate knowledge i.e., 661 (12\%) were found among those who belonged to age group 15 to 30 years. Among 13390, positive attitude regarding towards HIV/AIDS was found among 1071 (8\%) women and negative attitude was found among 12319 (92\%) women. Among 12319 women, highest negative attitude was found among 46 and above age group i.e., 4559 (37\%), 4188 (34\%) negative attitude was found among 31 to 45 years age group and 3572 (29\%) negative attitude was found among 15 to 30 years age group.

Women residing in urban settings had more appropriate knowledge i.e., 63.6\% with more negative attitude towards HIV/AIDS i.e., 53.8\%. Among marital status, single women had highest appropriate knowledge i.e., 57.6\% and more negative attitude towards HIV/AIDS i.e., 51.9\% than married women. Women with higher education had more appropriate knowledge i.e., 37.9\% and more negative attitude i.e., 30\% towards HIV/AIDS than women having no formal education; whereas, women with richest (highest) wealth quintile had more appropriate knowledge i.e., $37.4 \%$ and more negative attitude i.e., 26.5\% towards HIV/AIDS. Appropriate knowledge towards HIV/AIDS transmission i.e., $56.3 \%$ and more negative attitude i.e., 42.1\% towards HIV/AIDS was observed among women who had daily access to media than women who had no or sometimes access to mass media. 
Table 4. Socio-demographic factors of respondents with respect to knowledge and attitude towards HIV/AIDS transmission(N=13390)

\begin{tabular}{|c|c|c|c|c|}
\hline \multirow[t]{2}{*}{$\begin{array}{l}\text { Socio-demographic } \\
\text { variables }\end{array}$} & \multicolumn{2}{|c|}{$\begin{array}{l}\text { Respondents Knowledge Score } \\
(\mathrm{N}=13390)\end{array}$} & \multicolumn{2}{|c|}{$\begin{array}{l}\text { Respondents Attitude Score } \\
(\mathrm{N}=13390)\end{array}$} \\
\hline & $\begin{array}{l}\text { Appropriate } \\
\text { Knowledge } \\
5490(41 \%)\end{array}$ & $\begin{array}{l}\text { Inappropriate } \\
\text { Knowledge } \\
7900(59 \%)\end{array}$ & $\begin{array}{l}\text { Positive } \\
\text { Attitude } \\
1071(08 \%)\end{array}$ & $\begin{array}{l}\text { Negative } \\
\text { Attitude } \\
12319(92 \%)\end{array}$ \\
\hline \multicolumn{5}{|l|}{ Age of Women (years) } \\
\hline $\begin{array}{l}15-30 \\
31-45 \\
46 \text { and above }\end{array}$ & $\begin{array}{l}661(12 \%) \\
1877(34.1 \%) \\
2531(46.1 \%)\end{array}$ & $\begin{array}{l}3318(42 \%) \\
2654(33.6 \%) \\
2349(29.7 \%)\end{array}$ & $\begin{array}{l}407(38 \%) \\
343(32 \%) \\
321(30 \%)\end{array}$ & $\begin{array}{l}3572(29 \%) \\
4188(34 \%) \\
4559(37 \%)\end{array}$ \\
\hline \multicolumn{5}{|c|}{ Type of place of residence } \\
\hline $\begin{array}{l}\text { Rural } \\
\text { Urban }\end{array}$ & $\begin{array}{l}2000(36.4 \%) \\
3490(63.6 \%) \\
\end{array}$ & $\begin{array}{l}4300(54.4 \%) \\
3600(45.6 \%)\end{array}$ & $\begin{array}{l}610(57 \%) \\
461(43 \%)\end{array}$ & $\begin{array}{l}5690(46.2 \%) \\
6629(53.8 \%)\end{array}$ \\
\hline \multicolumn{5}{|l|}{ Marital Status } \\
\hline $\begin{array}{l}\text { Married } \\
\text { Single a }\end{array}$ & $\begin{array}{l}2327(42.4 \%) \\
3163(57.6 \%)\end{array}$ & $\begin{array}{l}4219(53.4 \%) \\
3681(46.6 \%)\end{array}$ & $\begin{array}{l}620(57.9 \%) \\
451(42.1 \%)\end{array}$ & $\begin{array}{l}5926(48.1 \%) \\
6393(51.9 \%)\end{array}$ \\
\hline \multicolumn{5}{|l|}{ Women Education } \\
\hline $\begin{array}{l}\text { No formal education } \\
\text { Primary } \\
\text { Secondary } \\
\text { Higher }\end{array}$ & $\begin{array}{l}100(2 \%) \\
1471(26.7 \%) \\
1839(33.4 \%) \\
2080(37.9 \%) \\
\end{array}$ & $\begin{array}{l}2162(27.3 \%) \\
2040(25.9 \%) \\
1855(23.5 \%) \\
1843(23.3 \%)\end{array}$ & $\begin{array}{l}332(31 \%) \\
268(25 \%) \\
246(23 \%) \\
225(21 \%)\end{array}$ & $\begin{array}{l}1930(15.7 \%) \\
3243(26.3 \%) \\
3448(28 \%) \\
3698(30 \%)\end{array}$ \\
\hline \multicolumn{5}{|l|}{ Wealth index } \\
\hline $\begin{array}{l}\text { Poorest } \\
\text { Poor } \\
\text { Middle } \\
\text { Rich } \\
\text { Richest } \\
\end{array}$ & $\begin{array}{l}12(0.2 \%) \\
971(17.7 \%) \\
1056(19.2 \%) \\
1397(25.5 \%) \\
2054(37.4 \%) \\
\end{array}$ & $\begin{array}{l}2441(30.9 \%) \\
1380(17.5 \%) \\
1375(17.4 \%) \\
1366(17.3 \%) \\
1338(16.9 \%) \\
\end{array}$ & $\begin{array}{l}420(39.2 \%) \\
183(17.1 \%) \\
177(16.5 \%) \\
164(15.3 \%) \\
127(11.9 \%)\end{array}$ & $\begin{array}{l}2033(16.5 \%) \\
2168(17.6 \%) \\
2254(18.3 \%) \\
2599(21.1 \%) \\
3265(26.5 \%) \\
\end{array}$ \\
\hline \multicolumn{5}{|l|}{ Access to media } \\
\hline $\begin{array}{l}\text { Not at all } \\
\text { Sometimes } \\
\text { Almost every day }\end{array}$ & $\begin{array}{l}368(6.7 \%) \\
2031(37 \%) \\
3091(56.3 \%)\end{array}$ & $\begin{array}{l}2994(37.9 \%) \\
2607(33 \%) \\
2299(29.1 \%)\end{array}$ & $\begin{array}{l}526(49.1 \%) \\
345(32.2 \%) \\
200(18.7 \%)\end{array}$ & $\begin{array}{l}2836(23 \%) \\
4293(34.9 \%) \\
5190(42.1 \%)\end{array}$ \\
\hline
\end{tabular}

aSingle (separated, widowed and divorced); Mean Age $=32$ years; Standard Deviation $=10.2$

\subsection{Relationship of Socio-demographic}

\section{Characteristics with Knowledge and Attitude towards HIV/AIDS Transmission}

The predictors of the knowledge and attitude towards HIV/ AIDS transmission (Table 5) Presented high odds of having appropriate knowledge among 46 and above years women (2.19 (1.97-2.96)); women with higher level of education (3.56 (2.95-4.29)); urban women (1.67 (1.22-2.65)); women belongs to richest (highest) wealth quintile ((2.24 (1.71-2.95)) and daily access to media (2.32 (1.99-2.86)) whereas, low odd ratio was observed among married women $(0.53$ (0.38-0.93)). Similarly, in attitude high odds ratio was observed among women 46 and above age (2.01 (1.94-2.59)); higher education (3.01 (2.46-3.69)); urban women (1.83 (1.30-2.86)); women in richest wealth quintile $(2.19(1.62-2.52))$; everyday access to media (2.01 (1.63-2.48)) and low odds ratio among married women $(0.76(0.50-0.97))$.
The results concluded significant associations with sociodemographic factors (Table 5) i.e., women age, women education, wealth index and access to media have p-values $=0.001$ respectively, whereas, type of place of residence have $\mathrm{p}$-value $=0.01$ while, marital status have $\mathrm{p}$-value $<0.05$ with knowledge and attitudes of women towards HIV/AIDS.

\section{Discussion}

The studies based on assessing knowledge and attitudes researches were valuable prior to any experimental study ${ }^{22}$. This study examines the relationship of socio-demographic factors with the knowledge and attitude of ever married women regarding HIV/AIDS by using data of MICS 2014 of Punjab province of Pakistan. In the study under discussion cumulative percentage of appropriate knowledge among study participants is $41 \%$ while responses pertaining to inappropriate knowledge account for $59 \%$. Precisely there was poor knowledge about 
Table 5. Binary logistic regression of socio-demographic characteristics with knowledge and attitude towards HIV/AIDS transmission $(\mathrm{N}=13390)$

\begin{tabular}{|c|c|c|}
\hline \multirow[t]{2}{*}{ Socio- demographic variables } & Knowledge & Attitude \\
\hline & $\begin{array}{l}\text { Odd Ratio } \\
95 \% \text { CI b }\end{array}$ & $\begin{array}{l}\text { Odd Ratio } \\
95 \% \text { CI b }\end{array}$ \\
\hline $\begin{array}{l}\text { Age of Women } \\
15-30 \\
31-45 \\
46 \text { and above }\end{array}$ & $\begin{array}{l}1 \\
1.44(1.81-2.30)^{* * *} \\
2.19(1.97-2.96)^{* * *}\end{array}$ & $\begin{array}{l}1 \\
1.32(1.12-1.82)^{\star * *} \\
2.01(1.94-2.59)^{\star * *}\end{array}$ \\
\hline $\begin{array}{l}\text { Women Education } \\
\text { No formal education } \\
\text { Primary } \\
\text { Secondary } \\
\text { Higher }\end{array}$ & $\begin{array}{l}1 \\
1.69(1.42-2.01)^{\star * *} \\
2.02(1.71-2.37)^{\star * *} \\
3.56(2.95-4.29)^{\star * *}\end{array}$ & $\begin{array}{l}1 \\
1.13(1.01-1.27)^{\star \star \star} \\
1.88(1.58-2.24)^{\star \star \star} \\
3.01(2.46-3.69)^{\star \star \star}\end{array}$ \\
\hline $\begin{array}{l}\text { Type of Place of Residence } \\
\text { Rural } \\
\text { Urban }\end{array}$ & $\begin{array}{l}1 \\
1.67(1.22-2.65)^{\star *}\end{array}$ & $\begin{array}{l}1 \\
1.83(1.30-2.86)^{\star *}\end{array}$ \\
\hline $\begin{array}{l}\text { Marital Status } \\
\text { Married } \\
\text { Single a }\end{array}$ & $\begin{array}{l}0.53(0.38-0.93) * \\
1\end{array}$ & $\begin{array}{l}0.76(0.50-0.97) * \\
\mathbf{1}\end{array}$ \\
\hline $\begin{array}{l}\text { Wealth Index } \\
\text { Poorest } \\
\text { Poor } \\
\text { Middle } \\
\text { Rich } \\
\text { Richest } \\
\end{array}$ & $\begin{array}{l}1 \\
1.44(1.11-1.88)^{\star * \star} \\
1.97(1.52-2.55)^{\star \star \star} \\
2.22(1.69-2.87)^{\star \star *} \\
2.24(1.71-2.95)^{\star * \star}\end{array}$ & $\begin{array}{l}1 \\
1.28(1.01-1.53)^{\star * *} \\
1.60(1.34-2.09)^{\star * *} \\
2.03(1.56-2.49)^{\star * *} \\
2.19(1.62-2.52)^{\star * *}\end{array}$ \\
\hline $\begin{array}{l}\text { Access to media } \\
\text { Not at all } \\
\text { Sometimes } \\
\text { Almost everyday }\end{array}$ & $\begin{array}{l}1 \\
1.21(1.06-1.37)^{* * *} \\
2.32(1.99-2.86)^{* * *}\end{array}$ & $\begin{array}{l}1 \\
1.52(1.22-1.63)^{\star * *} \\
2.01(1.63-2.48)^{\star * *}\end{array}$ \\
\hline
\end{tabular}

a Single (separated, widowed and divorced); b CI (Confidence Interval); 1 (reference category).

${ }^{*}$ p-value $<0.05 ;{ }^{* *}$-value $=0.01 ;{ }^{* *}$ p-value $=0.001$

HIV/AIDS, lack of right knowledge, places Pakistani women at great risk of HIV infection. In this study, as far as trend in attitude is concerned $08 \%$ women showed positive attitude toward HIV/AIDS while $92 \%$ showed negative attitude that can be portrayed due to poor knowledge.

Some significant findings concluded from the secondary analysis of some socio-demographic including age of women, type of place of residence, marital status, educational status, wealth index and access to media with knowledge and attitude regarding HIV/AIDS among ever married women. Among age group, the odds of having good knowledge towards HIV/ AIDS transmission were higher among 46 and above than 15 to 30 years age women. These findings were found congruent with the study findings of Ankunda and his coauthors ${ }^{1}$. The older women ages, the more negative their prejudiced attitudes towards HIV/AIDS. These finding were found congruent with Masoudnia ${ }^{23}$ results which showed that people's negative attitudes toward HIV/AIDS was associated with their knowledge and age.

Level of education signified improved knowledge towards HIV/AIDS transmission. Respondents with higher education showed high odds of appropriate knowledge than respondents with no formal education. This coincides with the study findings of Ankunda and his coauthors'. Negative attitude towards HIV/AIDS coincides with the study findings of Masoudnia ${ }^{23}$. Respondents improved knowledge for HIV/AIDS transmission and discriminatory attitude towards people with HIV/AIDS was due to the fact that firstly education enhanced knowledge of a person in general; secondly educated person had more exposure to modern media and modern health facilities.

Current study identified that there was significant difference in knowledge and attitudes regarding HIV/AIDS among urban and rural resident women. Women residing in urban areas had high odds of having good knowledge towards HIV/AIDS 
transmission than rural areas. This result coincides with study findings by Ankunda and his coauthors ${ }^{1}$, Huy and others ${ }^{18}$ and Latif ${ }^{8}$ reported that urban women had greater knowledge for HIV/AIDS transmission than rural women. Whereas, in attitude domain, HIV/AIDS being a spreadable disease (fear of infection); individual who had better knowledge towards HIV/AIDS transmission were expected to hold more negative, stigmatizing and discriminatory attitudes towards people living with HIV/AIDS ${ }^{24}$.

As far as the results pertaining to marital status were concerned, it showed variance in the level of knowledge and attitude between single and married women. Married women had low odds of having good knowledge towards HIV/AIDS transmission than single (widowed, divorced or separated) women. The findings were found consistent with the study carried by Ankunda and his coauthors ${ }^{1}$ among Vietnamese women who described that married women had less appropriate knowledge towards HIV/AIDS transmission compared to single women. Positive attitude were found by married women towards HIV/AIDS than single women. These study findings coincides with the study findings of Huy and others $^{18}$. It can be the reason married women believe that marriage was a safety to precarious sexual behaviors.

Wealth index was also found positively associated with HIV/AIDS knowledge level. Women in richest wealth quintile showed significant high odds of having good and appropriate knowledge towards HIV/AIDS transmission than women in poorest wealth quintile. Similar results were found in the study conducted by Yaya and his co-associates ${ }^{20}$ and Ankunda and Asiimwe ${ }^{1}$. It can be due to the reason that being more economically strong was linked with education, more access to resources, employment and better access to information. Higher the wealth index, the more negative discriminatory attitude towards HIV/AIDS coincides with the study findings of Alaba ${ }^{24}$ and Mutahar and his co-associates ${ }^{25}$. This was due to the fact that people with higher economic background had more good appropriate knowledge, educated, more access to media, over protective and over conscious about their health issues.

Lastly, daily access to mass media i.e., reading newspaper or magazine, listen to the radio and watch television showed significant high odds of having good and appropriate knowledge towards HIV/AIDS transmission than those who sometimes or had no access to media. Similar findings were found in the study carried out by Ankunda and Asiimwe ${ }^{1}$ who said that people visiting social networking sites had more knowledge towards HIV/AIDS transmission; it could be due to the reason that mass media is source of information and awareness campaigns regarding HIV/AIDS were usually going on. Additionally, daily access to media yields more negative discriminatory attitude towards HIV/AIDS ${ }^{26}$. This argument may be explained by the fact that despite of having high odds of good knowledge about HIV/AIDS transmission; HIV/ AIDS remains dreaded and had not wane out the beliefs and perceptions about the disease transmission.

\section{Conclusion}

Despite of having high odds of appropriate knowledge among Pakistani married women towards HIV/AIDS transmission had not still wade out the misconceptions, social stigmas and discriminatory (negative) attitude of community towards people with HIV/AIDS. Programs need to be designed in order to reverse the negative attitude towards HIV/AIDS transmission which may be straightaway mandatory in this concern among Pakistani women who are vulnerable to HIV/ AIDS transmission.

\section{References}

1. Ankunda D, Asiimwe JB. Determinants of comprehensive knowledge of HIV/AIDS among women of the reproductive age (15-49) in Uganda. International Journal of Community Medicine and Public Health. 2017; 4(10):3530-35. https://doi. org/10.18203/2394-6040.ijcmph20174215

2. Asaduzzaman $M$, Higuchi $M$, Sarker MAB, Hamajima N. Awareness and knowledge of HIV/AIDS among married women in rural Bangladesh and exposure to media: a secondary data analysis of the 2011 Bangladesh Demographic and Health Survey. Nagoya Journal of Medical Science. 2016; 78(1):109-18. PMid:27019532 PMCid:PMC4767519

3. Zafar M, Nisar N, Kadir M, Fatmi Z, Ahmed Z, Shafique K. Knowledge, attitude and practices regarding HIV/AIDS among adult fishermen in coastal areas of Karachi. BMC Public Health. 2014; 14(1):437. https://doi.org/10.1186/1471-2458-14-437 PMid:24886122 PMCid:PMC4046521

4. Rehan M, Waheed U, Sarwar M, Arshad M, Satti HS, Zaheer HA. Knowledge, attitude, practices and awareness regarding HIV/AIDS among University Students of Islamabad and Rawalpindi, Pakistan. Annals of Pakistan Institute of Medical Sciences. 2016; 12(2):86-9.

5. Dugdale C, Zaller N, Bratberg J, Berk W, Flanigan T. Missed opportunities for HIV screening in pharmacies and retail clinics. Journal of Managed Care Pharmacy. 2014; (4):339-45. https://doi.org/10.18553/jmcp.2014.20.4.339 PMid:24684638 PMCid:PMC4465258

6. Granich R, Gupta S, Hersh B, Williams B, Montaner J, Young B, et al. Trends in AIDS deaths, new infections and ART coverage in the top 30 countries with the highest AIDS mortality burden; 19902013. Plos One. 2015; 10(7):e0131353. https://doi.org/10.1371/ journal.pone.0131353 PMid:26147987 PMCid:PMC4493077

7. Peck RN, Shedafa R, Kalluvya S, Downs JA, Todd J, Suthanthiran $\mathrm{M}$, et al. Hypertension, kidney disease, HIV and antiretroviral therapy among Tanzanian adults: a cross-sectional study. BMC 
Medicine. 2014; 12(1):125. https://doi.org/10.1186/s12916-0140125-2 PMid:25070128 PMCid:PMC4243281

8. Latif A. Effects of socio-demographic factors on knowledge about transmission of aids among reproductive aged women: evidence from Multiple Indicator Cluster Survey (Mics) 2011 Pakistan. The WomenAnnual Research Journal of Gender Studies. 2016; 8(8):101-27.

9. Nasir JA, Imran M, Zaidi SAA. HIV/AIDS awareness in Pakistan; binary logistic regression analysis of pdhs-2012-13. The Professional Medical Journal. 2015; 22(5):603-09.

10. Faust L, Yaya S, Ekholuenetale M. Wealth inequality as a predictor of HIV-related knowledge in Nigeria. BMJ Global Health. 2017; 2(4):e000461. https://doi.org/10.1136/bmjgh-2017-000461 PMid:29333285 PMCid:PMC5759704

11. Subaeti T, Demartoto A, Murti B. Socioeconomic factors and sexual behavior associated with HIV infection in population, in Kebumen District, Central Java. Journal of Health Promotion and Behavior. 2018; 03(01):56-65. https://doi.org/10.26911/thejhpb.2018.03.01.06

12. Wang W, Chen R, Ma Y, Sun X, Qin X, Hu Z. The impact of social organizations on HIV/AIDS prevention knowledge among migrants in Hefei, China. Globalization and Health. 2018; 14:41. https://doi.org/10.1186/s12992-018-0359-4 PMid:29695304 PMCid:PMC5918763

13. Gao N, Fu K, He W, Li R, Lou W. Cognition and attitude of bachelor dental students towards HIV/AIDS. Biomedical Research. 2017; 28(6):2578-82.

14. Neha S, Xiao Z. Knowledge, attitude and practice regarding HIV/ AIDS among Students in China. World Journal of AIDS. 2017; 07(04):247-59. https://doi.org/10.4236/wja.2017.74021

15. Bharati $M$, Bharati L. A study on knowledge of HIV/AIDS among adolescents of higher secondary school in Jajarkot district of Nepal. Journal of Chitwan Medical College. 2014; 4(9):43-5.

16. Rao TS, Ismail S, Shajahan A, Wylie K. Adolescent sex education in India: Current perspectives. Indian Journal of Psychiatry. 2015; 57(4):333-7. https://doi.org/10.4103/0019-5545.171843 PMid:26816418 PMCid:PMC4711229

17. Bureau of Statistics, Government of the Punjab. Multiple Indicator Cluster Surveys. Available from: http://bos.gop.pk/system/files/11.HIV_AIDS.pdf\#overlay-context=finalreport

18. Huy NV, Lee H-Y, Nam Y-S, Tien NV, Huong TTG, Hoat LN. Secular trends in HIV knowledge and attitudes among Vietnamese women based on the Multiple Indicator Cluster Surveys, 2000, 2006, and 2011: what do we know and what should we do to protect them? Global Health Action. 2016; 9(1):29247. https://doi. org/10.3402/gha.v9.29247 PMid:26950557 PMCid:PMC4780092

19. Lau FK, Jayakumar S, Sgaier SK. Understanding the socio-economic and sexual behavioral correlates of male circumcision across eleven voluntary medical male circumcision priority countries in southeastern Africa. BMC Public Health. 2015; 15(1):813. https://doi.org/10.1186/s12889-015-2135-1 PMid:26297202 PMCid:PMC4546248

20. Yaya S, Bishwajit G, Danhoundo G, Shah V, Ekholuenetale M. Trends and determinants of HIV/AIDS knowledge among women in Bangladesh. BMC Public Health. 2016; 16(1):812. https://doi.org/10.1186/s12889-016-3512-0 PMid:27535231 PMCid:PMC4989494

21. Salima N, Leah E, Stephen L. HIV testing among women of reproductive age exposed to intimate partner violence in Uganda. The Open Public Health Journal. 2018; 11(1):275-87. https://doi. org/10.2174/1874944501811010275

22. Nubed CK, Akoachere J-FTK. Knowledge, attitudes and practices regarding HIV/AIDS among senior secondary school students in Fako Division, South West Region, Cameroon. BMC Public Health.2016; 16(1):847. https://doi.org/10.1186/s12889016-3516-9 PMid:27549185 PMCid:PMC4994230

23. Masoudnia E. Public perceptions about HIV/AIDS and discriminatory attitudes toward people living with acquired immunodeficiency syndrome in Iran. SAHARA-J: Journal of Social Aspects of HIV/AIDS. 2015; 12(1):116-22. https://doi.org /10.1080/17290376.2015.1123644 PMid:26726933

24. Alaba OO. Modeling Determinants of Discriminatory Attitude towards HIV/AIDS Patients in Zambia: A Generalized Additive Mixed Model. West African Journal of Industrial and Academic Research. 2015; 13(1):71-81.

25. Mutahar R, Yenni N. Determinants of Indonesian people attitudes towards people living with HIV/AIDS (PLWHA). International Journal of Public Health Research Special Issue. 2011; 224-228.

26. Odimegwu CO, Alabi O, Wet ND, Akinyemi JO. Ethnic heterogeneity in the determinants of HIV/AIDS stigma and discrimination among Nigeria women. BMC Public Health. 2018; 18(1):763. https://doi.org/10.1186/s12889-018-5668-2 PMid:29914438 PMCid:PMC6006838 